\title{
Turpin v. Sortini: Recognizing the Unsupportable Cause of Action for Wrongful Life
}

In Turpin v. Sortini, ${ }^{1}$ the California Supreme Court considered for the first time a cause of action for "wrongful life." 2 In the first decision of its kind by a state's highest court, ${ }^{3}$ the court granted a cause of action to a child born with a hereditary defect that allegedly burdens her life to the extent that she would have been better off had she never been born. ${ }^{4}$ While the court broke with what was then unanimous precedent in other American jurisdictions by allowing any recovery at all, it nevertheless limited the child's recovery to special dainages, denying her claim for general damages.

This Note argues that the wrongful life cause of action cannot be justified under established tort principles or legal policies. A corrcct analysis of this claim reveals a fundamental conceptual flaw: the impossibility of establishing the existence of harn. ${ }^{5}$ The Turpin court acknowledged this flaw, yet granted special dannages nonetheless. This Note argues that the policy considerations upon which the court justified awarding special damages do not support the court's decision. Rather, important policy considerations argue against recogmition of the wrongful life cause of action.

Part I of this Note sets forth the facts of Turpin and sunimarizes the majority and dissenting opinions. Part II presents the legal background of the wrongful life claim. Part III analyzes the wrongful life

1. 31 Cal. 3d 220, 643 P.2d 954, 182 Cal. Rptr. 337 (1982).

2. "Wrongful life" is the name commonly given an action by a child seeking damages for having been brought into existence. The corresponding action by the parents seeking damages for the birth of a child is commonly called "wrongful birth." This terminology was adopted by the Turpin court, 31 Cal. 3d at 225 n.4, 643 P.2d at 957 n.4, 182 Cal. Rptr. at 340 n.4, and will be retained in this Note.

3. On January 6,1983 , the Washington Supreme Court recognized the wrongful life and wrongful birth causes of action. Harbeson v. Parke-Davis, Inc., 98 Wash. 2d 460, 656 P.2d 483 (1983). As to the wrongful life claim, that court echoed the Turpin opinion in many respects and reached an identical result. See infro notes 10-22 and accompanying text.

4. 31 Cal. 3d at 232, 643 P.2d at 961,182 Cal. Rptr. at 344.

5. While harm and injury are distinct concepts, in the typical tort case the distinction is insignificant. As a result, the courts often confuse the two in imprecise language. For the sake of clarity and consistency, this Note will nse the terminology of the Restatement of Torts, wlich defines injury as an invasion of a legally protected mterest and harm as an actual dctriment. See REsTATEMENT (SECOND) OF TORTS $§ 7$ (1965). 
cause of action in the light of traditional tort principles and demonstrates the fundamental flaw in this claim. It argues that this obstacle to recovery cannot be overcome, despite the efforts of the Turpin court and others to do so. This Note concludes that the court should have refused to recognize the wrongful life cause of action in any forn.

I

The CASE

\section{A. The Facts}

On August 23, 1977, the plaintiff, Joy Turpim, was born suffering froin hereditary total deafness. ${ }^{6}$ Her parents brought an action im lier behalf $^{7}$ alleging that Joy was born because Dr. Adam J. Sortini ${ }^{8}$ negligently failed to diagnose the lereditary deafness of leer older sister, Hope. Joy's parents maintained that had Hope's condition been correctly diagnosed, they would have been aware of the probability that their future children would inherit the same condition, and Joy never would have been conceived. The coinplaint sought

(1) general damages for being 'deprived of the fundamental right of a child to be born as a whole, functional human being without total deafness' and (2) special damages for the 'extraordinary expenses for specialized teaching, training and hearing equipment' which she will incur during her lifetime as a result of her hearing impairment. ${ }^{9}$

\section{B. The Opinions}

\section{The Majority}

The supreme court held that "while a plaintiff-child in a wrongful hife action may not recover general damages for being born impaired as opposed to not being born at all, the child ... . may recover special damages for the extraordinary expenses necessary to treat the hereditary ailment." 10 In reaching its decision, the court rejected one rationale for denying wrongful life recovery that had been adopted by

6. 31 Cal. 3d at 224, 643 P.2d at 956, 182 Cal. Rptr. at 339.

7. The same complaint stated causes of action on behalf of Joy's older sister Hope and of the girls' parents. The trial court sustained a demurrer to Joy's cause of action and to her parents' claim for damages for emotional distress. Joy's appeal reached the supreme court following a judgment of dismissal and was the only action the court decided in this case. The parents' wrongful birth cause of action remained pending in the trial court at the time of the supreme court's decision. Id. at 224 n.3, 643 P.2d at 956 n.3, 182 Cal. Rptr. at 339 n.3.

8. Dr. Sortini was "a licensed professional specializing in the diagnosis and treatment of speech and hearing defects." Id. at 224, 643 P.2d at 956, 182 Cal. Rptr. at 339. The rehabilitation center and hospital where Dr. Sortini practiced and various unnamed parties were included as defendants. $I d$.

9. Id at 224,643 P.2d at 956, 182 Cal. Rptr. at 339.

10. Id. at 239,643 P.2d at 966, 182 Cal. Rptr. at 349. 
numerous other courts ${ }^{11}$ - that the plaintiff has suffered no legally cognizable imjury because "considerations of public policy dictate a conclusion that life-even with the most severe of impairments-is, as a matter of law, always preferable to nonlife." 12 The court questioned whether "a contrary conclusion would 'disavow' the sanctity and value of less-than-perfect human life," 13 and rejected the assertion that Califorma's public policy establishes as a matter of law that any life is preferable to nonexistence. The majority doubted that there is a "societal consensus" that life for individuals affected by severe defects is always preferable to nonexistence. ${ }^{14}$ The court acknowledged instead a public policy supporting "the right of each individual to make his or her own determination as to the relative value of life and death." 15 Recognizing that an unborn child cannot make her own decision, the court reasoned that her parents could be trusted to decide in her interest whether she should be born. ${ }^{16}$

In contrast, the court approved the reasoning of those courts in other jurisdictions that had denied recovery on the ground that there are no rationally ascertainable damages in a wrongful life action. ${ }^{17}$ Noting that the purpose of dainages im a tort action is to place the plaintiff in the position she would have been in but for the tort, the court observed that to determine whether a wrongful life plaintiff liad

11. See, e.g., Phillips v. United States, 508 F. Supp. 537 (D.S.C. 1980); Berman v. Allan, 80 N.J. 421, 404 A.2d 8 (1979); Gleitman v. Cosgrove, 49 N.J. 22, 227 A.2d 689 (1967), overruled on other grounds by Berman v. Allan, 80 N.J. 421 , 404 A.2d 8 (1979); Becker v. Schwartz, 46 N.Y.2d 401, 386 N.E.2d 807, 413 N.Y.S.2d 895 (1978); Stewart v. Long Island College Hosp., 35 A.D. 2d 531, 313 N.Y.S.2d 502 (1970), affd, 30 N.Y.2d 695, 283 N.E.2d 616, 332 N.Y.S.2d 640 (1972); Speck v. Finegold, 268 Pa. Super. 342, 372, 408 A.2d 496, 512 (1979), aff'd in part and rev'd in part, 497 Pa. 77, 439 A.2d 110 (1981); Duner v. St. Michael's Hosp., 69 Wis. 2d 766, 233 N.W.2d 372 (1975).

12. 31 Cal. 3d at 232, 643 P.2d at 961,182 Cal. Rptr. at 344.

13. Id (citing Berman v. Allan, 80 N.J. 421, 430, 404 A.2d 8, 12-13 (1979) and Phillips v. United States, 508 F. Supp. 537, 543 (D.S.C. 1980)).

14. Id. at 234,643 P.2d at 962-63, 182 Cal. Rptr. at 345-46.

15. Id. at $233,643 \mathrm{P} .2 \mathrm{~d}$ at $962,182 \mathrm{Cal}$. Rptr. at 345 . The court found this public policy in $\S 7186$ of the Califorma Health and Safety Code, Cal. Health \& SAFETY CoDE $\$ 7186$ (West Supp. 1983) (terminal patients may elect to withhold or withdraw life-sustaining procedures). The court also referred to Superimtendent of Belchertown v. Saikewicz, 373 Mass. 728, 370 N.E.2d 417 (1977), and In re Quinlan, 70 N.J. 10, 355 A.2d 647 (1976), both cases dealing with a terminally-ill patient's right to forego life-sustaining or -prolonging ineasures. See infra notes 60-64 and accompanying text.

16. 31 Cal. 3d at 233, 643 P.2d at 962, 182 Cal. Rptr. at 345.

17. Id. at 234-35, 643 P.2d at 963, 182 Cal. Rptr. at 346. See Stills v. Gratton, 55 Cal. App. 3d 698, 705-06, 127 Cal. Rptr. 652, 656-57 (1976); Gleitman v. Cosgrove, 49 N.J. 22, 29-31, 227 A.2d 689, 692-93 (1967), overruled on other grounds by Berman v. Allan, 80 N.J. 421, 404 A.2d 8 (1979); Becker v. Schwartz, 46 N.Y.2d 401, 410-11, 386 N.E.2d 807, 811-12, 413 N.Y.S.2d 895, 899-900 (1978); Speck-v. Finegold, 268 Pa. Super. 342, 364-65, 408 A.2d 496, 508 (1979), affd in part and rev'd in part, $497 \mathrm{~Pa} .77,439$ A.2d 110 (1981); Dumer v. St. Michael's Hosp., 69 Wis. 2d 766, 772-73, 233 N.W.2d 372, 375-76 (1975). 
suffered any harm would require the impossible comparison between her actual condition and "the unknowable status of never havimg been born." 18 The majority poimted out that in a wrongful life case the obstacle is not just difficulty im ascertaining damages, such as might be the case in a standard personal injury action where harm has been conceded. In an ordmary personal injury action, the jury is capable of awarding daunages for nonpecumary harm because "the value of a healthy existence over an impaired existence is within the experience [or] imagination of most people. The value of nonexistence-its very nature-however, is not."19

As an additional obstacle to allowing general damages, the court cited the "benefit doctrine," which requires that "the value of the benefit conferred ... . [be] considered in mitigation of dainages, to the extent that this is equitable." 20 In a wrongful life case the benefit doctrine would require reducing the damages for pain and suffering by the value of being alive, a benefit that the defendant conferred on the plaintiff. The court concluded that both elements of this "liarn-benefit equation" are incalculable, and therefore "a reasoned, nonarbitrary award of general damage is simply not obtainable."21

The court then held that a claim by the same child for the medical and other expenses necessary to treat the condition with which she was born is not subject to the same objections as is the general dainages claim. First, these expenses would not have been incurred had the defendant not been negligent. Second, they are readily ascertainable and

18. 31 Cal. 3d at 236, 643 P.2d at 964, 182 Cal. Rptr. at 347; W. Prosser, HandBooK of THE LAW OF TORTS $\$ 55$, at 335-38 (4th ed. 1971). Quoting a leading wrougful life case, the court observed: "To recognize a right not to be born is to enter an area in which no one can find his way.'" 31 Cal. 3d at 235, 643 P.2d at 963, 182 Cal. Rptr. at 346 (quoting Gleitinan v. Cosgrove, 49 N.J. 22, 63, 227 A.2d 689, 711 (1967) (Weintraub, J., dissenting in part), aff d in part and rev'd in part, 497 Pa. 77, 439 A.2d 110 (1981)).

19. 31 Cal. 3d at 236, 643 P.2d at 963-64, 182 Cal. Rptr. at 346-47 (quoting Speck v. Finegold, $268 \mathrm{~Pa}$. Super. 342, 372, 408 A.2d 496, 512 (1979) (Spaeth, J., concurring in part and dissenting in part), aff'd in part and rev'd in part, $497 \mathrm{~Pa} .77,439 \mathrm{A.2d} 110$ (1981)).

20. 31 Cal. 3d at 236, 643 P.2d at 964, 182 Cal. Rptr. at 347 (citing Restatement (SECOND) OF TORTS $\$ 920$ (1979)). Section 920 provides:

When the defendant's tortious conduct has caused harm to the plaintiff or to his property and in so doing has conferred a special benefit to the interest of the plaintiff that was harmed, the value of the benefit conferred is considered in mitigation of damages, to the extent that this is equitable.

RESTATEMENT (SECOND) OF TORTS $\$ 920$ (1979).

21. 31 Cal. 3d at 237, 643 P.2d at 964, 182 Cal. Rptr. at 347. The court also cited Borer v. American Airlines, 19 Cal. 3d 441, 563 P.2d 858, 138 Cal. Rptr. 302 (1977), and Baxter v. Superior Court, 19 Cal. 3d 461, 563 P.2d 871, 138 Cal. Rptr. 315 (1977), in which daunages for loss of society and companionship in the parent-child relationship were denied on the grounds, inter alia, that money damages would not provide ineaningful compensation for the plaintifr's loss and that damages for such an intangible loss would be very difficult to measure. $19 \mathrm{Cal}$. 3d at $447-48,464,563$ P.2d at 858, 871, 138 Cal. Rptr. at 302, 315. The court observed that both of these factors were present in the instant case. 31 Cal. 3d at 237,643 P.2d at 964, 182 Cal. Rptr. at 347. 
regularly awarded in professional inalpractice actions. Third, these expenses will, in many instances, be vital to the child's well-being or survival. Finally, the benefit doctrine does not preclude recovery, as it does in the case of general damages. Here the expenses harm the child's economic interest, while being alive benefits only ler interest in "general physical, einotional and psychological well-being."22 For these reasons the court ruled that a wrongful life plaintiff could recover special dainages. ${ }^{23}$

\section{The Dissent}

Justice Mosk, in a dissenting opmion in which Chief Justice Bird concurred, criticized the inconsistency of awarding special damages while denying general dainages. He argued that the court should have followed Curlender v. Bio-Science Laboratories, ${ }^{24}$ a California Court of Appeal decision that had recognized a cause of action for wrongful life without limiting the type of damages recoverable. ${ }^{25}$

Justice Mosk quoted extensively from Curlender in arguing that the fact that the plaintiff would not exist but for the defendant's negligence should pose no obstacle to compensating the plaintiff for both pecuniary and nonpecuniary harnı. ${ }^{26}$ He inaintained that general primciples of tort law mandating recovery for all detriment proximately caused by a defendant's wrong apply as well to a wrongful life claim as to any other. ${ }^{27}$ Finally, Justice Mosk argued that the difficulty inherent in translating such subjective states as an infant's pain and suffering into inonetary terms does not justify denying recovery in a case where harin has been established. ${ }^{28}$

22. $31 \mathrm{Cal}$. 3d at 237, 643 P.2d at 964, 182 Cal. Rptr. at 347. The Restatement of Torts provides for setoff of benefit only when it is "to the interest of the plaintiff that was harmed." RESTATEMENT (SECOND) OF TORTS § 920 (1979), quoted at supra note 20.

Justice Newinan concurred in the result, although he expressed the belief that such basic changes in the law should be left to the legislature. $31 \mathrm{Cal} .3 \mathrm{~d}$ at $240,643 \mathrm{P} .2 \mathrm{~d}$ at $966,182 \mathrm{Cal}$. Rptr. at 349.

23. $31 \mathrm{Cal} .3 \mathrm{~d}$ at $239,643 \mathrm{P} .2 \mathrm{~d}$ at $966,182 \mathrm{Cal}$. Rptr. at 349.

24. 106 Cal. App. 3d 811, 165 Cal. Rptr. 477 (1980).

25. 31 Cal. 3d at 240, 643 P.2d at 966, 182 Cal. Rptr. at 349 (Mosk, J., dissenting).

26. Id. at 240-42,643 P.2d at 966-67, 182 Cal. Rptr. at 349-50 (Mosk, J., dissenting) (quoting 106 Cal. App. 3d at 828-31, 165 Cal. Rptr. at 488-90).

27. 31 Cal. 3d at 241, 643 P.2d at 967, 182 Cal. Rptr. at 350 (Mosk, J., dissenting) (citing Cal. CrvLl CoDE $\$ \S 3282$ and 3333, and Crisci v. Security Ins. Co., 66 Cal. 2d 425, 433, 426 P.2d 173, 178, 58 Cal. Rptr. 13, 18 (1967)).

28. 31 Cal. 3d at 242, 643 P.2d at 967, 182 Cal. Rptr. at 350 (Mosk, J., dissenting) (citing Capelouto v. Kaiser Found. Hosp., 7 Cal. 3d 889, 893, 500 P.2d 880, 883, 103 Cal. Rptr. 856, 859 (1972)). 


\section{II \\ LEGAL BACKGROUND}

The term "wrongful hife" was first used in Zepeda v. Zepeda," the first case in an American jurisdiction to consider a damage claim by a child for his own birth. ${ }^{30}$ Although the term has been applied to suits alleging various types of harm, ${ }^{31}$ today it is generally understood to apply to an action by a child afflicted with some defect who alleges that but for the defendant's neghigence he or she would not have been born and thus would not have had to suffer the defect. The essence of a wrongful life claim is "that [defendants], through their neghigence, [have] forced upon [the child] the worse of . . . two alternatives[,] . . . that nonexistence-never having been born-would have been preferable to existence in [the] diseased state." "32 Before Turpin, all but two courts that had considered wrongful life claims denied them. ${ }^{33}$ Parents,

29. 41 Ill. App. 2d 240, 190 N.E.2d 849 (1963), cert. denied, 379 U.S. 945 (1964).

30. Zepeda involved an action by a child against his father, claiming damages resulting from the child's illegitimate birth. Id.

31. See, e.g., Stills v. Gratton, 55 Cal. App. 3d 698, 127 Cal. Rptr. 652 (1976) (unsuccessful abortion); Berman v. Allan, 80 N.J. 421, 404 A.2d 8 (1979) (failure to inform plaimtiff's mother, pregnant at age thiry-eight, of the availability of amniocentesis to detect plamtiffs Down's Syndrome); Gleitman v. Cosgrove, 49 N.J. 22, 227 A.2d 689 (1967) (failure to diagnose rubella in plaintiff's pregnant inother and inform her of the advisability of abortion); Williains v. State, 18 N.Y.2d 481, 223 N.E.2d 343, 276 N.Y.S.2d 885 (1966) (failure to prevent the rape of the plaintiffs mother while an inmate of a state mental institution, which resulted in plaintiff's illegitimate birth); Beardsley v. Wierdsma, 650 P.2d 288 (Wyo. 1982) (failed sterilization).

32. $31 \mathrm{Cal}$. 3d at 232, 643 P.2d at 961, $182 \mathrm{Cal}$. Rptr. at 344 (quoting Speck v. Finegold, 268 Pa. Super. 342, 372, 408 A.2d 496, 511-12 (1979) (Spaeth, J., concurring in part and dissenting in part), affd in part and rev'd in part, $497 \mathrm{~Pa} .77,439$ A.2d 110 (1981)).

33. E.g., White v. Umited States, 510 F. Supp. 146 (D. Kan. 1981) (applying Kansas law); Phillips v. Umited States, 508 F. Supp. 537 (D.S.C. 1980) (applying South Carolina law); Boone v. Mullendore, 416 So. 2d 718 (Ala. 1982); DiNatale v. Lieberman, 409 So. 2d 512 (Fla. App. 1982); Maggard v. McKelvey, 627 S.W.2d 44 (Ky. App. 1981); Sherlock v. Stillwater Clinic, 260 N.W.2d 169 (Minn. 1977); Miller v. Duhart, 637 S.W.2d 183 (Mo. App. 1982); Stribling v. deQuevedo, 288 Pa. Super. 436, 432 A.2d 239 (1980); Jacobs v. Theimer, 519 S.W.2d 846 (Tex. 1975); Beardsley v. Wierdsma, 650 P.2d 288 (Wyo. 1982). See also supra note 11. Since Turpin, the second district of the California Court of Appeal has heard two wrongful life cases. In the first it dismissed a wrongful life action brought for the birth of a healthy child born after an unsuccessful sterilization. Morris v. Frudenfeld, 135 Cal. App. 3d 23, 185 Cal. Rptr. 76 (1982). In the secoud it ordered that the plaintiff be allowed to amend ler complaint to seek special damages as allowed by Turpin. Call v. Kezirian, 135 Cal. App. 3d 189, 185 Cal. Rptr. 103 (1982). Decisions after Turpin in other jurisdictions which have refused to recognize the cause of action include Dorlin v. Providence Hosp., 118 Micl. App. 831, 325 N.W.2d 600 (1982) (specifically rejected Turpin approach and refused to allow even cause of action limited to special damages), and Payton v. Abbott Labs, 386 Mass. 540, 437 N.E.2d 171 (1982) (no recovery where defendant can show that, but for their mothers' ingestion of DES, plaintiffs would never have been born).

A New York appellate court recognized the cause of action in Park v. Chessin, 60 A.D.2d 80, 400 N.Y.S.2d 110 (1977), but was overruled in this regard by Becker v. Schwartz, 46 N.Y.2d 401, 386 N.E.2d 807, 413 N.Y.S.2d 895 (1978). In Curlender v. Bio-Scieuce Laboratories, $106 \mathrm{Cal}$. App. 3d 811, 165 Cal. Rptr. 477 (1980), the California Court of Appeal allowed full recovery to a child plaimtiff afflicted with Tay-Sachs disease. The supreme court in Turpin overruled Curlender 
however, may generally recover for harm caused to them by a birth that they would have prevented but for the defendant's negligence. ${ }^{34}$ These "wrongful birth" claims are very often allowed in the same action in which a wrongful life claim is denied. ${ }^{35}$

Decisions denying the wrongful life cause of action liave followed two basic lines of reasoning. ${ }^{36}$ The first is that a wrongful life plaimtiff calmot have suffered any injury in having been born. This position is often expressed in terms of a fundamental policy that life, however defective, is preferable to nonexistence, and that a wrongful life plaintiff therefore has not suffered any legally cognizable harm. ${ }^{37}$

The second line of argument poimts to the logical impossibility of establishing the existence of any harm, a necessary element of a plaimtiff's cause of action for negligence. ${ }^{38}$ The concept of harm requires a

insofar as it authorized geueral damages. 31 Cal. 3d at 239, 643 P.2d at 966, 182 Cal. Rptr. at 349. Since Turpin, only the Washingtou court has recognized wrongful life. See supra note 3.

34. See, e.g., Robak v. United States, 658 F.2d 471 (7th Cir. 1981); Custodio v. Bauer, 251 Cal. App. 2d 303, 59 Cal. Rptr. 463 (1967) (unsuccessful sterilization); Rivera v. State, 94 Misc. 2d 157, 404 N.Y.S.2d 950 (Ct. Cl. 1978) (same); Troppi v. Scarf, 31 Mich. App. 240, 187 N.W.2d 511 (1971) (druggist negligently filled prescription for contraceptives with mild tranquilizers); Harbeson v. Parke-Davis, Inc., 98 Wasl. $2 \mathrm{~d} \mathrm{460,656} \mathrm{P.2d} 483$ (1983) (failure to warn of the risks of birth defects from taking Dilantin during pregnancy). Some courts lhave denied recovery for the wrongful birth of a healthy child. E.g., Coleman v. Garrison, 349 A.2d 8 (Del. 1975); Sala v. Tomlinson, 73 A.D.2d 724, 422 N.Y.S.2d 506 (1979); Morris v. Frudenfeld, 135 Cal. App. 3d 23, 185 Cal. Rptr. 76 (1982); Rieck v. Medical Protective Co., 64 Wis. 2d 514, 219 N.W.2d 242 (1974). See generally Kashi, The Case of the Unwanted Blessing: Wrongful Life, 31 U. MIAMI L. REv. 1409 (1977); Kelley, Wrongful Life, Wrongful Birth, and Justice in Tort Law, 1979 WASH. U.L.Q. 919; Commeut, Wrongful Birth and Wrongful Life: Questions of Public Policy, 28 LOYOLA L. REv. 77 (1982).

35. See, e.g, Phillips v. United States, 508 F. Supp. 537 (D.S.C. 1980); DiNatale v. Lieberman, 409 So. 2d 512 (Fla. App. 1982); Maggard v. McKelvey, 627 S.W.2d 44 (Ky. Ct. App. 1981); Bernan v. Allan, 80 N.J. 421, 404 A.2d 8 (1979); Becker v. Schwartz, 46 N.Y.2d 401, 386 N.E.2d 807, 413 N.Y.S.2d 895 (1978); Speck v. Finegold, 268 Pa. Super. 342, 408 A.2d 496 (1979), affd in part and rev'd in part, $497 \mathrm{~Pa} .77,439 \mathrm{~A} .2 \mathrm{~d} 110$ (1981).

36. Courts have advanced a variety of other rationales. See, e.g. Zepeda v. Zepeda, 41111. App. 2d 240, 190 N.E.2d 849 (1963) (apprehension regarding the potential scope of liability), cert. denied, 379 U.S. 945 (1964); Gleitman v. Cosgrove, 49 N.J. 22, 227 A.2d 689 (1967) (a public pohicy against abortion); Slawek v. Stroh, 62 Wis. 2d 295, 215 N.W.2d 9 (1974) (deferral to the legislature); Becker v. Schwartz, 46 N.Y.2d 401, 386 N.E.2d 807, 413 N.Y.S.2d 895 (1978) (absence of riglit to be born whole); Elliott $v$. Brown, 361 So. 2d 546 (Ala. 1978) (absence of riglt not to be born at all). However, none of these rationales has found any significant following, and courts most often use the lines of argument discussed in the text. 31 Cal. 3d at 232, 643 P.2d at 961,182 Cal. Rptr. at 344.

37. See, e.g., Bennan v. Allan, 80 N.J. 421, 429, 404 A.2d 8, 12-13 (1979); Gleitman v. Cosgrove, 49 N.J. 22, 30-31, 227 A.2d 689, 693 (1967), overruled on other grounds by Berman v. Allan, 80 N.J. 421, 404 A.2d 8 (1979); Becker v. Sclıwartz, 46 N.Y.2d 401, 410-11, 386 N.E.2d 807, 81112,413 N.Y.S.2d $895,899-900$ (1978). The majority in Turpin found the "no legally cognizablc harm" theory to be an insufficient ground for refusing damages. 31 Cal. 3d at 232-34, 643 P.2d at 961-63, 182 Cal. Rptr. at 344-46. See infra text acconjpanying notes 52-64.

38. The Turpin court observed that in order to recover the plaimtiff must establisli: (1) a duty of care owed by the defendant to the plaintiff, and (2) a brcach of that duty, which is (3) the proximate cause of (4) actual loss or liarm to the plaimtiff. 31 Cal. 3d at 229, 643 P.2d at 960, 182 Cal. Rptr. at 343. See also Budd v. Nixeu, 6 Cal. 3d 195, 200, 491 P.2d 433, 436, 98 Cal. Rptr. 849, 
comparison of the plaintiff's actual situation with the position she would have been in but for the tort. ${ }^{39}$ The great majority of courts that have considered the wrongful life cause of action have concluded, as did the Turpin court, that it is impossible for a jury to make the necessary comparison between a plaintiff's actual condition and nonexistence, which the plaintiff claims would be preferable. ${ }^{40}$

Some commentators have discussed the "benefit doctrine" of tort law im connection with wrongful life claims. ${ }^{41}$ This doctrine requires that the value of the harm to the plaintiff be offset by the value of any imcidental benefit that the defendant's conduct may have conferred on the "imterest of the plaintiff which was harned." 42 Since wrongful life had not been recognized in other jurisdictions, courts applied the doctrine only im wrongful birth actions, and treated it inconsistently. The imconsistency centered around the "interest harmed" language of the Restatement of Torts. Most courts set off both pecuniary and nonpecuniary benefits against the aggregate of damages. ${ }^{43}$ Soine courts and commentators, however, argued that pecuniary benefits should be set off only against pecuniary harn, and nonpecuniary benefits against

852 (1971); 4 B. WitKIN, Summary of CaLIFornia LaW Torts $\$ 488$, at 2749 (8th ed. 1974); W. Prosser, supra note $18, \S 30$, at 143 . While the court acknowledged that all the elements of a tort cause of action must be established in order for the plaintiff to recover, it indicated that harm was the only element at issue in this case. $31 \mathrm{Cal}$. 3d at 229-30, 643 P.2d at 960, $182 \mathrm{Cal}$. Rptr. at 343.

39. Stills v. Gratton, 55 Cal. App. 3d 698, 706, 127 Cal. Rptr. 652, 656-57 (1976); RESTATEMENT (SECOND) OF TORTS \& 7 (1965). 4 B. WITKN, supra note 38, § 842, at 3137.

40. See Stills v. Gratton, 55 Cal. App. 3d 698, 705-06, 127 Cal. Rptr. 652, 656-57 (1976); Gleitman v. Cosgrove, 49 N.J. 22, 29-31, 227 A.2d 689, 692-93 (1967), overnuled on other grounds by Berman v. Allan, 80 N.J. 421, 404 A.2d 8 (1979); Becker v. Schwartz, 46 N.Y.2d 401, 410-11, 386 N.E.2d 807, 811-12, 413 N.Y.S.2d 895, $899-900$ (1978); Speck v. Finegold, 268 Pa. Super. 342, 364-65, 408 A.2d 496, 508 (1979), affd in part and rev'd in part, $497 \mathrm{~Pa} .77,439$ A.2d 110 (1981); Dumer v. St. Michael's Hosp., 69 Wis. 2d 766, 772-73, 233 N.W.2d 372, 375-76 (1975). See also Robertson, Toward Rational Boundaries of Tort Liability for Injury to the Unborn: Prenatal Injuries, Preconception Injuries and Wrongful Life, 1978 DUKE L.J. 1401, 1443-45; Tedeschi, On Tort Liability for "Wrongful Life," 1 IsRAEL L. Rev. 513, 533 (1966). But see Capron, Tort Liability in Genetic Counseling, 79 CoLUM. L. REv. 618, 635-36 (1979).

41. See e.g., Tcdeschi, supra note 40, at 530; Capron, supra note 40, at 683. While commentators have discussed the doctrine in connection with both wrongful life and wrongful birth causes of action, courts have only applied it to the latter. In wrongful birth actions the doctrine requires a comparison of the burden of an unplanned or defective child with the benefits of raising that child. See, e.g., Custodio v. Bauer, 251 Cal. App. 2d 303, 59 Cal. Rptr. 463 (1967); Gleitman v. Cosgrove, 49 N.J. 22, 29-30, 227 A.2d 689, 693 (1967), overruled on other grounds by Berman v. Allan, 80 N.J. 421, 404 A.2d 8 (1979); Robertson, supra note 40, at 1446-48.

42. See supra note 20 and accompanying text.

43. See, e.g., Stills v. Gratton, 55 Cal. App. 3d 698, 709, 127 Cal. Rptr. 652, 659 (1976) ("defendants may prove any offsets for benefits conferred"); Troppi v. Scarf, 31 Mich. App. 240, 262, 187 N.W.2d 511, 521 (1971) (weighing shonld be done by jury); Christensen v. Thornby, 192 Minn. 123, 126, 255 N.W. 620, 622 (1934) (birth of a healthy child does not constitute harm, even after failed sterilization); Shaheen v. Knight, 11 Pa. D. \& C.2d 41, 45-46 (C.P. Lycoming County 1957) (no harm because joys incident to parenthood outweigh expenses). See also Capron, supra note 40 , at 632,643 . 
nonpecuniary harm, since each is a separate "interest" of the plaintiff. ${ }^{44}$

\section{III \\ ANALYSIS}

A wrongful life action is fundamentally different fron other tort actions in that the defendant's negligence is the cause of the plaintiff's very existence. This Part argues that the wrongful life action is inherently flawed. This Part also argues that the atteinpts of the Turpin court and otlers to overcome this flaw liave been inadequate.

The fundaniental conceptual flaw of the wrongful life action is that it is impossible to establish that the plaintiff las suffered liarm. ${ }^{45}$ In a negligence action, damages are awarded to restore the plaintiff to the position she would liave been in liad the tort not been committed. ${ }^{46}$ Thus, to establish harm in a wrongful life action the court inust compare the plaintiff's impaired condition with nonexistence, which would have been the plaintiff's condition had the defendant not acted negligently. ${ }^{47}$ No such comparison is possible because nonexistence is entirely outside of hunan experience. This conceptual flaw separates the wrongful life claim from all traditional tort actions. ${ }^{48}$

\section{A. The Turpin Approach}

In denying general daniages, the Turpin court acknowledged that the obstacle to recovery in a wrongful life case is that it is impossible to

44. See, e.g., Kashi, supra note 34, at 1415, 1431; Note, Judicial Limitations on Damages Recoverable for the Wrongful Birth of a Healthy Infant, 68 VA. L. REv. 1311, 1323 (1982); RESTATEMENT (SECOND) OF TORTS $\$ 920$ comment b, at 510 (1979). Cf. Custodio v. Bauer, 251 Cal. App. 2d 303, 59 Cal. Rptr. 463 (1967) (interpreting even inore narrowly the "interest harmed"). The Turpin court took the latter approach. 31 Cal. 3d at 239, 643 P.2d at 965-66, 182 Cal. Rptr. at $348-49$.

45. 31 Cal. 3d at 234-35, 643 P.2d at 963,182 Cal. Rptr. at 346.

46. Id at 232, 643 P.2d at 961, 182 Cal. Rptr. at 344. See generally ReSTATEMENT (SECOND) of TORTS $\S 901$ comment a (1979); Stills v. Gratton, 55 Cal. App. 3d 698, 706, 127 Cal. Rptr. 652, 656-57 (1976); 4 B. WITKIN, supra note $38, \S 842$, at 3137.

47. See supra text accompanying note 18. See generally Robertson, supra note 40 , at 1443 . 45; Tedeschi, supra note 40 , at 533 .

48. Accord Eisbrenner v. Stanley, 106 Mich. App. 351, 366, 308 N.W.2d 209, 213 (1981). One commentator has poimted out that in a traditional tort context, life is the sine qua non of any assessment of tort damages. Comment, Wrongful Life and a Fundamental Right to Be Born Healthy: Park v. Chessin; Becker v. Scwartz, 27 Buffalo L. Rev. 537, 557 (1978). In other words, all standard considerations of injury are made within the confines of human existence as we know it. Cf. CAL. Crv. CoDE $\$ 29$ (West 1982) (providing that an unborn child is to be considered a person "so far as may be necessary for its interests in the event of its subsequent birth"). A jury can at least imagine, based on common experience, see Capron, supra note 40 , at $658-59$, the difference between a healthy existence and one with injuries. Both conditions are part of life, a condition common to all persons. Any attempt to measure existence against nonexistence inoves outside this common experience, since no one knows, or knows anyone who knows, what nonexistence is like. See $31 \mathrm{Cal}$. 3d at 235-36, 643 P.2d at 963-64, 182 Cal. Rptr. at 346-47. 
determine that the plaintiff has been harmed. ${ }^{49}$ The court quoted approvingly froin Gleitman $v$. Cosgrove, a leading wrongful life case: ${ }^{.50}$ " 'Ultimately, the infant's complaint is that he would be better off not to have been born. Man, who knows nothing of death or nothingness, cannot possibly know whether that is so." "si

Despite this seeming recognition of the unique nature of the wrongful hife claim, other aspects of the Turpin opinion indicate that the court failed to appreciate fully its imphications. First, the inajority claimed that nonexistence can, in severe cases, be preferable to life with defects. Second, the court placed more emphasis on the difficulty of assessing the value of harm, rather than on the impossibility of estabhishing its existence. Finally, it allowed special damages despite its acknowledgment that the plaintiff could not prove she had suffered a detriment in being born. This Section will discuss these problems in turn.

\section{The Preferability of Nonexistence}

The court first demonstrated its failure to appreciate the impossibility of proving harm in a wrongful life action by indicating that plaintiffs with severe defects may have been better off not having been born. ${ }^{52}$ Recognizing that it would be difficult to so characterize the plaintiff in Turpin, whose "only affliction" was deafness, the majority referred to "[o]ther wrongful life cases," involving inore severe defects. $^{53}$ As an exainple, the court suggested the plaintiff in Curlender, ${ }^{54}$ and histed the numerous debilitating effects of Tay-Sachs disease from which that child suffered. ${ }^{55}$ The majority concluded that it could not presume life to be preferable to nonexistence in such cases because there 1might not be a "societal consensus" that being ahve was worth suffering the burdens iniposed by the defect. ${ }^{56}$

The court's reasoning ignores the logical need to coinpare nonexistence with life before reaching any conclusion as to the relative values of the two. By asserting that nonexistence inay in soine cases be preferable to life, the court contradicted its earher statement that the necessary comparison is beyond human experience. Those courts that have

49. "[I]t is simply impossible to determine in any rational or reasoned fashion whether the plaintiff has in fact suffered injury in being born impaired rather than not being born . . . ." 31 Cal. 3d at 235, 643 P.2d at 963, 182 Cal. Rptr. at 346. See also supra notes 17-19 and accoinpanying text.

50. 49 N.J. 22, 227 A.2d 689, 711 (1967), overruled on other grounds by Berman v. Allen, 80 N.J. 421,404 A.2d 8 (1979).

51. Id. at 63,227 A.2d at 711 (Weintraub, C.J., dissenting in part).

52. 31 Cal. 3d at 234-35, 643 P.2d at 962-63, 182 Cal. Rptr. at 345-46.

53. Id.

54. 106 Cal. App. 3d 811, 165 Cal. Rptr. 477 (1980).

55. 31 Cal. $3 \mathrm{~d}$ at 234 n.10, 643 P.2d at 963 n.10, 182 Cal. Rptr. at 346 n.10.

56. Id. at 234,643 P.2d at $962-63,182$ Cal. Rptr. at $345-46$. 
drawn the contrary conclusion that life is always preferable to nonexistence ${ }^{57}$ have made the same mistake. The Turpin court's rejection of the absolute presumption of the preferability of life $\mathrm{e}^{58}$ was proper, not because an opposite conclusion is possible, but because no conclusion is possible. ${ }^{59}$

In support of its position that nonexistence may be preferable to life, the court pointed to California's "Natural Death Act."60 However, the statute cannot be fairly said to support this broad assertion. It provides only that an adult may decide, upon learning of a terminal condition, that life-sustaining procedures which would serve only to postpone death may be withheld or withdrawn. The decision must be made by the affected individual. ${ }^{61}$ The patient is prohibited from authorizing the withholding of life-support if she has been diagnosed as pregnant, ${ }^{62}$ suggesting, if anything, that the "right . . . to make . . . [a] determination as to the relative value of life and death" ${ }^{33}$ does not extend to decisions by a parent affectimg the life of an unborn child. ${ }^{64}$

\section{The Difficulty of Damage Calculation}

The court's discussion of the speculative nature of damage calculation provides a second indication of its failure to appreciate the conceptual flaw of wrongful life. If, as the court acknowledged, harni to the plaimtiff cannot be shown, ${ }^{65}$ any difficulty in calculatimg damages is irrelevant. Nonetheless, the court stated that, even if it were possible to prove the existence of harm, "it would be impossible to assess general

57. See, e.g., Phillips v. United States, 508 F. Supp. 537 (D.S.C. 1980); Stills v. Gratton, 55 Cal. App. 3d 698, 127 Cal. Rptr. 652 (1976); Berman v. Allan, 80 N.J. 421, 404 A.2d 8 (1979); Gleitman v. Cosgrove, 49 N.J. 22, 227 A.2d 689 (1967), overruled on other grounds by Berman v. Allan, 80 N.J. 421, 404 A.2d 8 (1979); Becker v. Schwartz, 46 N.Y.2d 401, 386 N.E.2d 807, 413 N.Y.S.2d 895 (1978); Stewart v. Long Island College Hosp., 35 A.D. 2d 531, 313 N.Y.S.2d 502 (1970), affd, 30 N.Y.2d 695, 283 N.E.2d 616, 332 N.Y.S.2d 640 (1972); Dunier v. St. Michael's Hosp., 69 Wis. 2d 766, 233 N.W.2d 372 (1975).

58. 31 Cal. 3d at 232-34, 643 P.2d at 961-63, 182 Cal. Rptr. at 344-46.

59. See Capron, supra note 40, at 650-53; Comment, Wrongful Life and Wrongful Birth Causes of Action-Suggestions for a Consistent Analysis, 63 MARQ. L. REv. 611,618 (1980).

60. 31 Cal. 3d at 233, 643 P.2d at 962, 182 Cal. Rptr. at 345 (citing Cal. Health \& SAFETY CODE $\S 7186$ (West Supp. 1982) (permitting terminally ill patients to withhold or withdraw lifesustaining measures)).

61. Cal. Health \& SAfety Code $\$ 7188$ (West 1982).

62. Id.

63. 31 Cal. 3d at 233, 643 P.2d at 962,182 Cal. Rptr. at 345.

64. Furthermore, the Act specifically provides that "[no] physician . . . shall be criminally or civilly hable for failing to effectuate the directive of the . . patient pursuant to this subdivision." CaL. Health \& SAFETY CODE § 7191(c) (West Supp. 1982). If the legislature saw fit to ensure that a physician cannot be liable for failing to honor the express directive of a mature adult patient, it must not have contemplated liability to a child who could not have been consulted as to her preference.

65. See supra notes $17-19,49-51$ and accompanying text. 
damages in any fair, nonspeculative manner."66 This language implies that it is the value of harm rather than its existence that is in doubt.

The court sought support for its position in the decisions that demed a cause of action for loss of affection and society in the parentchild relationship. ${ }^{67}$ One reason damages were denied in those cases was that the intangible nature of the harm made calculation of damages "very difficult."68 The court characterized the assessment of damages im a wrongful life case as "much more problematical" than in the loss-of-society cases, implymg that difficulty of calculation was the primary reason for denying damages. ${ }^{69}$

The court cited the benefit doctrime as an addtional factor contributimg to the difficulty of calculation of damages. The benefit doctrime requires damages for any harm inflicted to be offset by the value of any benefits conferred to the interest harmed. ${ }^{70}$ The court found the elements of the harm-benefit equation for a wrongful life cause of action particularly difficult to reduce to inonetary terms. In the court's estimation, the harm consists of pain and suffermg while the benefits to the plaintiff are "a physical existence with the capacity to both receive and give love and pleasure as well as to experience pain and suffering."71 This reasoning ignores the irrelevance of the benefit doctrine when it has not been determined that the plaintiff has even suffered harn. It is further evidence that difficulty of calculation was what led the court to deny general damages, and not the more fundamental problein of the impossibility of establishing harm. ${ }^{72}$

\section{The Granting of Special Damages}

The court's failure to appreciate the impossibility of proving harm im a wrongful life action is especially evident in its decision to award special damages. The majority attempted to justify an award of special damages by arguing that: (1) special damages are readily ascertain-

66. $31 \mathrm{Cal} .3 \mathrm{~d}$ at 238,643 P.2d at 965,182 Cal. Rptr. at 348.

67. Borer v. American Airlines, 19 Cal. 3d 441, 563 P.2d 858, 138 Cal. Rptr. 302 (1977); Baxter v. Superior Court, 19 Cal. 3d 461, 563 P.2d 871, 138 Cal. Rptr. 315 (1977).

68. 31 Cal. 3d at 237, 643 P.2d at 964, 182 Cal. Rptr. at 347 (citing Borer v. American Airlines, 19 Cal. 3d 441, 563 P.2d 858, 138 Cal. Rptr. 302 (1977) and Baxter v. Superior Court, 19 Cal. 3d 461, 563 P.2d 871, 138 Cal. Rptr. 315 (1977)).

69. 31 Cal. 3d at 237, 643 P.2d at 964,182 Cal. Rptr. at 347.

70. See supra note 20 and accompanying text.

71. 31 Cal. 3d at 236-37, 643 P.2d at 964, 182 Cal. Rptr. at 347.

72. Denying damages because they are uncertain or difficult to measure would seem to be contrary to California case law. See Dillon v. Legg, 68 Cal. 2d 728, 746-48, 441 P.2d 912, 924-25, 69 Cal. Rptr. 72, 84-85 (1968). Cf. Story Parchment Co. v. Paterson Parchment Paper Co., 282 U.S. 555, 563 (1931) (damages resulting from breach should not be denied just because uncertain). See also 2 F. HARPER \& F. JAMES, TORTs $\$ 25.3$, at 1306 (1956); Capron, supra note 40, at 634; Comment, supra note 48, at 558; Comment, Wrongful Life, The Right Not To Be Born, 54 TUL. L. REv. 480, 496-97 (1980). 
able; (2) the expenses compensated by special damages are often burdensome to the plaintiff; and (3) no corresponding benefit is conferred on the plaintiff that would offset the amount of special dainages. ${ }^{73}$

The argument that special damages should be awarded because "they are the kind of pecuniary losses which are readily ascertainable"74 assuines an answer to "the threshold question . . . whether the plaintiff has in fact suffered an injury . ..."75 Yet, as the court acknowledged, the impossibility of answering this threshold question makes it irrelevant whether the expenses sought are easily measured.

The majority's next argument, that the plaimtiff's medical expenses will place a significant burden on her fainily and may be necessary to her survival and well-being, ${ }^{76}$ fails to consider that the existence of burdensome expenses does not prove that she has been harined. Nevertheless, the court expressed concern that these expenses would prove to be an imequitable burden on the plaintiff or her family, or that there inight be cases in which a child's parents would be unavailable and the burden would be left on the child alone. The majority asserted that the afflicted child's receipt of necessary medical expenses should not depend "on the wholly fortuitous circumstance of whether the parents are available to sue and recover such dainages." 77

The court's concern is unfounded, however, since under existing California law the burdensorne expenses of a severely defective child will not be thrust involuntarily upon the child or her family without compensation by the defendant. California allows the parents to maintain a wrongful birth action to recover these extraordmary costs. ${ }^{78}$ The parents are responsible for the child's support during minority, and this duty of support will continue after the child's inajority if she is unable

73. The court argued in addition that special damages should be recoverable because the defendant caused the expenses. 31 Cal. $3 d$ at 238, 643 P.2d at 965, 182 Cal. Rptr. at 348. However, this is equally true of the plaintiff's pain and suffering, yet the court considered the establishment of causation alone insufficient to warrant an award of general damages. See supra notes 49 . 51 and accoinpanying text.

The court also argued that "it would be illogical and anomalous to permit only parents, and not the child, to recover for the cost of the child's own medical care." 31 Cal. 3d at 238, 643 P.2d at 965,182 Cal. Rptr. at 348 . Yet the parents are the only ones who can establish that they have suffered harin. In their case, the coinparison that inust be made is between their condition without the child and their condition with her. Id. These two alternatives are part of common cxperience. See Capron, supra note 40, at 632-43; Note, Father and Mother Know Best: Defining the Liability of Physicians for Inadequate Genetic Counseling, 87 YALE L.J. 1488, 1502-03 (1978). It is not at all anomalous to award damages to a plaimtiff who can establish that he has suffered harm, while denying thein to one who cannot.

74. 31 Cal. 3d at 238, 643 P.2d at 965,182 Cal. Rptr. at 348.

75. Id. at 235, 643 P.2d at 963,182 Cal. Rptr. at 346.

76. Id. at 238, 643 P.2d at 965,182 Cal. Rptr. at 348.

77. Id.

78. Stills v. Gratton, 55 Cal. App. 3d 698, 707-09, 127 Cal. Rptr. 652, $657-59$ (1976); Custodio v. Bauer, 251 Cal. App. 2d 303, 323-24, 59 Cal. Rptr. 463, $476-77$ (1967). 
to support herself. ${ }^{79}$ Therefore, the parents of a severely defective child who will have to support her after majority will be able to recover postmajority expenses..$^{80}$ In addition, if the parents are unavailable, the state is obligated to support the child. ${ }^{81}$ Thus, the court's concern that a severely defective child may be unable to pay for expensive medical care is unfounded. That the child may one day be indigent is not by itself sufficient reason for the court to recognize a wrongful life cause of action, given the state's statutory obligation to support the child in such circumstances.

Unless a child can support lierself during her lifetime, her parents will be able to recover the expenses associated with her condition. Therefore only a wrongful life plaintiff capable of supporting herself would bear these costs. As the court acknowledged, such a plaintiff is least able to argue that she has been harmed by being born. ${ }^{82}$ The court's primary justification for allowing a wrongful life action-that for severely defective children nonexistence could be better than lifedoes not apply to the only plaintiffs not already provided for under existimg law. ${ }^{83}$

Finally, the court incorrectly concluded that the benefit doctrine does not bar recovery of special damages. Relying on section 920 of the Restatement of Torts, the court reasoned that there should be a setoff only for benefits "to the imterest of the plaintiff that was harined." 84 The court noted that being alive benefited the plaintiff's interest in "general physical, emotional and psychological well-being," but not her monetary interest, and so the medical and other expenses should not be offset by a corresponding benefit. ${ }^{85}$ This type of imterest separation has often been suggested with regard to claims by parents, since their harms and benefits may rationally be separated and distmguished in this manner. ${ }^{86}$ However, where the defendant created all of the

79. CAL. Civ. CoDE $\S \S 196,196 a, 206$ (West 1982).

80. 31 Cal. 3d at 238 n.12, 643 P.2d at 965 n.12, 182 Cal. Rptr. at 348 n.12.

81. Cal. Welf. \& INST. CODE $\S 11250$ (premajority); id. $\S 11251$ (same); id. $\S 11253$ (postmajority). If someone else knowingly and voluntarily assumes the obligation of support from the parents or the state, the argument for compensation is less compelling.

82. 31 Cal. 3d at 234, 643 P.2d at 962,182 Cal. Rptr. at 345.

83. That the most burdensome expenses will be recovered by the parents also counters the court's argument that recognition of wrongful life will serve a deterrent purpose. See $31 \mathrm{Cal}$. 3d at 239 n. 15,643 P.2d at 966 n. 15,182 Cal. Rptr. at 349 n. 15.

84. $31 \mathrm{Cal}$. 3d at 237, 643 P.2d at 965,182 Cal. Rptr. at 347 . See supra note 20 and accompanying text.

85. 31 Cal. $3 d$ at $237,239,643$ P.2d at $964,965,182$ Cal. Rptr. at $347,348$.

86. See, e.g., Custodio v. Bauer, 251 Cal. App. 2d 303, 59 Cal. Rptr. 463 (1967); Kashi, supra note 34, at 1415; Note, supra note 44, at 1323; Note, supra note 73, at 1512-13. But see Capron, supra note 40, at 632, 643 (arguing that both financial and emotional burdens are "costs of parenthood" and should be offset by all benefits derived); accord Troppi v. Scarf, 31 Mich. App. 240, 262, 187 N.W.2d 511, 521 (1971); cf. Christensen v. Thornby, 192 Minn. 123, 126, 255 N.W. 
child's interests, it makes no sense to say that he benefited one of her interests but not another. If she had not been born, she would have no interests to benefit, economic or otherwise. ${ }^{87}$ The separation of interests requirement is entirely inappropriate in a situation in which the defendant is responsible for the plaintiff's existence. ${ }^{88}$

Even assuming a separation of interests, the benefit doctrine raises an additional difficulty in that the only plaintiff who will be in a position to recover in a wrongful life action will be one who will have the capacity to support herself after the age of inajority. Yet in order to be self-supporting, the plaintiff would necessarily have to be earning considerably more than she is spending in inedical costs. Thus, the defendant has conferred on her a net financial benefit in the amount of her entire earning capacity, less costs incurred as a result of her condition. Since the benefit that the defendant has conferred on the plaintiff's pecumary interest exceeds the harin to that interest, ${ }^{89}$ she should be barred from recovery.

The court's unsuccessful atteinpts to justify an award of special dainages betray its failure to appreciate fully the fundamental fiaw of a wrongful life claim. No wrongful life plaintiff, even with severe defects, can prove she has suffered harin, and the obstacle is not merely that damage calculations are speculative. The court acknowledged this fact, yet reached an inconsistent result. No damages of any kind can be awarded because it is impossible to know if the plaintiff is worse off as

620,622 (1934) (birth of a healthy child does not constitute harm, even after failed sterilization); Shaheen v. Knight, 11 Pa. D. \& C.2d 4l, 45-46 (C.P. Lycoming County 1957) (no harm beeause joys incident to parenthood outweigh expenses). See supra notes $41-44$ and accompanying text.

87. One commentator has argued that it is meaningless to talk of a "benefit conferred" in the wrongful life context because that which is said to be conferred-the plaintiff's very existencetranscends the concept of "giving" and "receiving." It is "being." Tedesehi, supra note 40, at 52930 .

88. It should be noted that the separation of interests requirement appears to have originated with the Restatement of Torts. No eartier case or cominentary expressly provides that only those benefits that are to the interest harmed shall be set off, though in several early cases the only harm and benefit involved were to land, which represeuts a single imterest. See, e.g., Mayo v. City of Springfield, 138 Mass. 70 (1884); Meier v. Portland Cable Ry. Cable Co., 16 Or. 500, 19 P. 610 (1888). Cf. Samples v. Kansas City Ry. Co., 232 S.W. 1049 (Mo. App. 1921) (suggesting that allegedly increased earning capacity (pecuniary benefit) resulting fron loss of a leg would have been set of against damages for the injury (nonpecuniary harm) but for contrary evidence showing decreased earning power).

According to early treatises and the only California case decided prior to the Restatement of Torts that dealt with the subject, the benefit doctrime required that when harm and benefit were conferred by the same act, the incasure of damages would be the net difference between the two, with no reference to separation of interests. See Hicks v. Drew, 117 Cal. 305, 49 P. 189 (1897) (citing G. Field, A Treatise on the LaW of Damages $§ 744$ (1876) and J. Sutherland, TreaTISE ON THE LAW OF DAMAges $\$ 1056$ (2d ed. 1893)).

89. Moreover, the defendant has also conferred on the plaintiff the "nonpecuniary" benefit of just being ahve, which the court acknowledged is invaluable. 31 Cal. 3d at 237, 643 P.2d at 964, 182 Cal. Rptr. at 347. 
a result of the defendant's negligence..$^{90}$

\section{B. Other Approaches}

Courts and commentators have suggested other approaches to solving the dilemma presented by a sympathetic plaintiff whose claim is frustrated by estabhshed principles of tort law. For example, it has been argued that recovery in wrongful life is required by the general principle that victims of torts should be fully compensated for all detriment that they suffer. Another approach has involved attempts to solve the riddle of comparing life with nonexistence by assigning values to each of the alternatives. Still others have sought to analogize the wrongful life claim to other torts, in an atteinpt to demonstrate that it really presents no unique obstacles. This Section will consider each of these approaches in turn.

Relying on general principles of recovery for tort victims, the dissent in Turpin argued that the plaintiff should have recovered both general and special damages. ${ }^{91}$ This was the approach taken in Curlender, from which the dissent quoted extensively. There the court reasoned that a plaintiff with Tay-Sachs disease "both exists and suffers," and a court should therefore be able to hold the defendant hable without estabhshing that the plaintiff is worse off for the defendant's conduct. ${ }^{92}$

The Turpin inajority accurately pointed out that " $[t]$ he basic fallacy of the Curlender analysis is that it ignores the essential nature of the defendants' alleged wrong and obscures the critical difference between wrongful life actions and the ordinary prenatal injury cases ...."93 This "critical difference" is that the defendant's negligence did not result in the plaintiff being born defective rather than whole, as would be the case in a prenatal injury case. Rather, had the defendant

90. See supra notes $45-51$ and accompanying text.

91. 31 Cal. 3d at 240-42, 643 P.2d at 966-67, 182 Cal. Rptr. at 349-50 (Mosk, J., dissenting) (citing Capelouto v. Kaiser Found. Hosp., 7 Cal. 3d 889, 500 P.2d 880, 103 Cal. Rptr. 856 (1972); Dillon v. Legg, 68 Cal. 2d 728, 441 P.2d 912, 69 Cal. Rptr. 72 (1968); Crisci v. Security Ins. Co., 66 Cal. 2d 425, 426 P.2d 173, 58 Cal. Rptr. 13 (1967); CAL. CIV. CoDE \$§ 3281, 3282, 3333 (West 1979)). The argument ignores the fact that an award of dainages without reference to what the plaintiff's position would have been but for the alleged tort is itself an exception to a general rule of damages. See 31 Cal. 3d at 232, 643 P.2d at 961, 182 Cal. Rptr. at 344. See also Capron, supro note 40, at 654-57; supra note 39 and accompanying text.

92. See $106 \mathrm{Cal}$. App. 3d at 829, $165 \mathrm{Cal}$. Rptr. at 488 (einphasis in original). Curlender was good law until inodified by Turpin.

93. 31 Cal. $3 \mathrm{~d}$ at 231,643 P.2d at $961,182 \mathrm{Cal}$. Rptr. at 344 . Though the Turpin majority criticized the failure of the Curlender court to address adequately the unique conceptual fiaw of the wrongful hife action, it cited similar general hability principles to support awardimg special damages. 31 Cal. 3d at 238, 643 P.2d at 965, 182 Cal. Rptr. at 348 (citing CAL. Crv. CoDE $\$ 1714$ (West Supp. 1982)). Thus, it too fell victim to the major weakness of this line of argumentbegging the fundameutal question, i.e., whether the plaimtiff is worse off as a result of the defendant's conduct, and has suffered harm for which she should be compensated. 
not been neghigent, the plaintiff would not have been born at all.94 Thus, without a determination that the plaintiff has been made worse off, it cannot be said that she has been harmed. ${ }^{95}$ Without harm, there can be no recovery. ${ }^{96}$

As another approach to overcoming the conceptual obstacle to wrongful life recovery, soine cominentators have proposed formulae for comparing the relative values involved in a wrongful hfe damage assessinent. One oft-cited contribution proposes a scheme in which "life without defects" has a positive value, ${ }^{97}$ life with defects has a negative value, and nonexistence has a neutral value. ${ }^{98}$ The proponent of this formula contends that it makes assessment of damages in a wrongful life case no inore difficult than in a standard personal injury case. ${ }^{99}$ Unfortunately, this facility is achieved by disregarding the inhercnt impossibility of assigning a value to nonexistence. ${ }^{100}$

While the author of this formula may have intended to circumvent the necessity of assigning nonexistence a value by giving it a neutral value, even a neutral value cannot be rationally assigned without some means of coinparison. This formula assumes that nonexistence is preferable to life with defects, and thus it assumes too inuch. For example, it fails to demonstrate that there is not some value in simply having the opportunity to live-that the mere capacity to experience joy, sorrow, pleasure, or pam may not make even the nost diseased existence superior to nothingness. ${ }^{101}$ However, neither this nor any other assertion about the relative values of existence and nonexistence can be demonstrated in any einpirical manner sufficient to form the basis for a judicial determination.

A third line of argunient is that the coinparison required in a wrongful life action is really not foreign to our legal system. Alexander Capron has argued that wrongful life calculations inerely involve a variation of the calculations ordinarily made in personal mjury and wrongful death actions. ${ }^{102}$ According to Capron, in personal mjury ac-

94. 31 Cal. 3d at 231, 643 P.2d at 961, 182 Cal. Rptr. at 344.

95. See supra notes $45-48$ and accompanying text.

96. See supra note 38.

97. This proposed variable imtroduces an additional conceptual difficulty. Standard tort damages are assessed with reference to the plaintiff's condition before the tort, not to some ideal state "without defects." The suggestion that "life without defects" be compared with the other variables assumes that there exists a life without defects. Since human beings are subject, without exception, to imperfections of varying severity, life without defects also is an unknowable quantity of no use in legal determinations.

98. Note, A Cause of Action for Wrongful Life: [A Suggested Analysis], 55 MinN. L. Rev. 58, 64-66 (1970).

99. Id.

100. See supra notes $45-48$ and accompanying text.

101. Cf. $31 \mathrm{Cal}$. 3d at 237, 643 P.2d at 964, $182 \mathrm{Cal}$. Rptr. at 347.

102. Capron, supra note 40. 
tions the jury compares the plaintiff's condition but for the tort ("normal") with his condition after the tort ("injured"). ${ }^{103}$ Similarly, Capron argues that in wrongful death actions the jury coinpares the condition before the tort ("normal") with that after ("nonexistence"). Capron concludes that a wrongful life action simply compares a variable froin the personal injury equation ("injured") with one from the wrongful death equation ("nonexistence"), and thus involves no unique conceptual difficulties. ${ }^{104}$

Capron's analysis mischaracterizes the nature of a dannage award in a wrongful death cause of action. The plaintiff does not receive compensation for the difference between the value of the deceased's life and nonexistence. Instead, the measure of dainages is simply the loss to the survivors or to the deceased's estate of the financial contributions that the deceased would have made during his or her working life. ${ }^{105}$ No account is taken of the relative value to the deceased of the pleasures and benefits of life and nonexistence. Thus a wrongful death action does not require a metaphysical coinparison between life and death.

It has been suggested that the comparison of life with nonexistence that wrongful life requires the court to inake is routinely made in personal injury cases where damages are awarded for shortening of life expectancy. While coinpensatory damages for the shortening of life expectancy have never been allowed in any American jurisdiction, ${ }^{106}$ they have long been allowed in the United Kingdom. ${ }^{107}$ However, even the courts of England, with whom this practice originated, have demonstrated some discomfort with granting recovery for this "Inetaphysical entity called "loss of life." "108 Perhaps most telling is the fact that recovery for this item of damages never exceeds the relatively nominal sum of $£ 500$, regardless of the number of years by which the life was

103. See supra notes $45-48$ and accompanying text.

104. Capron, supra note 40 , at 649.

105. D. Dobes, HaNdBooK on the LAW of Remedies $\S 8.3$, at 556-57 (1973); C. MCCoRMICK, HANDBOOK ON THE LAW OF DaMaGes §93, at 335-67 (1935).

106. D. DoBbS, supra note 105, \&8.1, at 549. The Court of Appeals for the Third Circuit expressed the prevailing sentiment among American courts when it held "that [awarding damages for shortened hife expectancy] is not feasible because of the incalculable variables which may enter into any attempt to place a value on life." Downie v. United States Lines Co., 359 F.2d 346, 347 (3d Cir. 1966). By contrast, American courts allow recovery of lost wages for the period between the plamtiff's shortened life expectancy and his preinjury working life expectancy, while British courts allow no such recovery. Id; Comment, The Measure of Damages for a Shortened Life, $22 \mathrm{U}$. CHI. L. REv. 505, 507-08 (1955).

107. See, e.g., Flint v. Lovell, [1935] I K.B. 354; Rose v. Ford, 1937 A.C. 826. See generally Baxter, Damages-Loss of Expectation of Life-Principles to Be Followed in Making AssessmentInterference by Court of Appeal in Quantum Awarded, 32 CAN. B. REv. 1018 (1954).

108. D. DoBBS, supra note 105, $\$ 8.1$, at 549; Comment, supra note 106, at 508. 
shortened or the relative quality of the plaintiff's life. ${ }^{109}$

Although in theory this rule suggests a valuation of the benefits of life, in practice the Enghish courts attempt no such calculation. They simply award a standard, nominal suin. Certainly this practice affords no support to the claim that courts are experienced at comparing life with nonexistence and that nonexistence can be found preferable. In fact, it has been observed that the very reason Enghish courts allow this claim is as a "symbolic declaration that life is valuable." 110 In no case has it been suggested that damages should not be awarded because death may have been preferable to life. ${ }^{111}$

Each of these atteinpts to justify wrongful life recovery fails to circumvent the impossible comparison of life with nonexistence required by the umique nature of this claim. Arguments based on general tort principles or analogies to standard tort actions ignore this fundamental distimction. Attempts to assign a value to nonexistence for purposes of damage assessment lack any rational justification, as they seek to value that which is outside human experience.

\section{CONCLUSION}

The court's recognition of the wrongful life cause of action is unjustified by traditional legal principles or sound public policy. The Turpin court failed to account fully and consistently for the fundamental flaw of the wrongful life claim -the inability to make the required comparison between the plamtiff's actual condition and nonexistence. Without this comparison, a plaintiff can never establish that she has suffered any detriment which would entitle her to recovery. While the court acknowledgcd this flaw, it nevertheless granted special damages to a plaintiff who could not demonstrate that she had suffered harm in being born. The policy considerations that led the court to contravene established legal principles do not require creation of a new cause of action. The same result could have been achieved through existing law without doing violence to traditional tort principles.

Attempts by the Turpin court and others to circumvent this fundamental obstacle to recovery have not adequately dealt with the inherent conceptual difficulties of the wrongful life claim. In view of the pecuhar nature of this cause of action, the supreme court should have followed the unanimous consensus of the other jurisdictions that had

109. See, e.g., Yorkshire Elec. Bd. v. Naylor, 1968 A.C. 529 (retaining this standard amount despite inflation). Recovery is higher in Canada. See Fleining, The Lost Years: A Problem in the Computation and Distribution of Damages, 50 CALIF. L. REV. 598, 601 \& n.15 (1962). See generally Hodgin, Damages for the "Lost Years," 32 N. IR. L.Q. 106 (1981).

110. D. DoBBS, supra note $105, \$ 8.1$, at 549-50 (emphasis added).

111. See Baxter, supra note 107; Coinunent, supra note 106, at 507-09. 
considered the question and refused to allow any recovery in a wrongful hife claim.

Kurtis J. Kearl*

- B.A. 1981, Brigham Young University; third-year student, Boalt Hall School of Law, University of California, Berkeley. 